\title{
Opportunistic methods of controlling vegetation, inspired by natural plant succession dynamics with special reference to natural outmixing tendencies in a gap regeneration
}

\author{
Jean-Philippe SCHÜTZ* \\ Swiss Federal Institute of Technology (ETH-Z) Zürich, Chair of Silviculture, 8092 Zürich, Switzerland
}

(Received 6 September 2002; accepted 28 February 2003)

\begin{abstract}
This paper outlines the prerequisites for research into natural and opportunistic methods of vegetation control. These methods must be chemical-free and respect naturalness, but must still be acceptable in terms of cost. These alternative regeneration control methods are discussed and illustrated. Firstly, weed control is influenced by the degree of shading during the regeneration process. The principle of antibiosis can also be used by sowing an admixture of herbs: these are invasive enough to flourish but favour the soil's biological activity (or other factors) enough to reduce weed development and so assist the regeneration process. In the long term, natural plant dynamics in temperate Central Europe lead to fairly regular stands, which are composed of relatively poor species, due to natural outmixing processes. This paper examines natural regeneration development in a 0.25 ha gap. Results show that starting from a very heterogeneous mixture of spontaneously regenerated seedlings (20 species), a considerable reduction in tree species in the dominant stand layer has taken place after 15 years. Outmixing differs depending on light conditions. Ash, which is an intolerant species, dominates in the gap centre, and beech, a tolerant species, dominates along the edge of the patch and under the old stand's shelter.
\end{abstract}

outmixing / natural regeneration / antibiosis / mixture / sowing

Résumé - Méthodes opportunistes de contrôle du développement de la végétation de parterre de coupe, inspirées de la dynamique naturelle de la succession végétale avec mention particulière des effets de démélange dans une régénération en trouée. Le présent texte souligne les conditions-cadre de la recherche de méthodes opportunistes de contrôle de la végétation du parterre de coupe. Elles se veulent libres d'intrants chimiques, respectueuses de la naturalité et acceptables en termes de coûts. On présente et illustre de telles méthodes alternatives de contrôle de la végétation. C'est tout d'abord l'utilisation de l'ombrage pendant le processus de régénération qui permet de bien gérer la végétation adventive. D'autres possibilités sont l'utilisation des principes d'antibiose et notamment l'installation par semis dirigé d'un mélange de plantes herbacées suffisamment prospère pour empêcher la prolifération d'autres plantes plus gênantes et pas trop incompatible avec un bon développement des ligneux désirés et ceci tout en agissant de façon favorable sur l'activité biologique du sol. À long terme le développement de la végétation ligneuse aboutit pour les conditions d'Europe centrale tempérée à la constitution de peuplements relativement pauvres en essences à cause de phénomènes de démélange. On présente les résultats du développement d'un rajeunissement naturel dans une trouée moyenne (d'environ 25 ares), constitué au départ de 20 espèces qui après 15 années démontre un effet très significatif de réduction du mélange d'essences dans l'étage dominant. Ce processus de démélange diffère en fonction de l'ombrage. Le frêne espèce héliophile domine les autres essences au centre de la trouée et le hêtre, sciaphile, dans les bords et en lisière.

démélange / rajeunissement naturel / antibiose / mélange / semis

\section{INTRODUCTION}

The aim of multipurpose silviculture is to satisfy all needs by respecting the diversity of processes, in the most multifunctional way possible [34, 37]. In Central Europe, natural forest tends to be rather monospecific and regular; this means that multipurpose silviculture must consider the search for more species, improve forest structure diversity and at the same time control the considerable cost of silvicultural operations. This is particularly evident during the natural regeneration phase, because crucial decisions must be taken regarding tree species composition and mixture patterns in relation to the fate of the mixtures. So, one challenge for densely populated countries in temperate Europe is to improve the diversity of forest habitat for socio-ethical reasons and to ensure that living conditions for fauna and flora are as diverse as possible. The aim, therefore, is to achieve extremely versatile silviculture technique in order to create appropriate distribution of regular, monospecific stands and vertically structured, intimate mixed ones. It also aims to produce light forests as well as dark ones. To do this,

\footnotetext{
* Corresponding author: jean-philippe.schuetz@env.ethz.ch
} 
it is necessary to adequately combine different regeneration techniques on different scales and at different rates of advancement. Forest ecosystems remain one of the last refuges of terrestrial naturalness. Another constraint - this time ethical - is to respect the basic conditions of naturalness, i.e. the naturality of processes. Forests must therefore be kept free of almost every chemical input foreign to the system. The policy of banning pesticides (or even chemical fertilisers) prevails in many European countries and is becoming more widespread. For example, the policy has been in place in Switzerland since 1973, and a ban on the use of chemical products in forests has been a part of forest legislation since 1991 [15, 39, 43].

The desire to reduce chemical applications means that research must be conducted into alternative, affordable methods of vegetation management. This applies to natural as well as artificial regeneration, especially on large regeneration cuts with no remaining shelter trees. The natural dynamics of plant succession can be used both for inspiration and imitation. Traditional methods of establishing appropriate stands are too expensive today, i.e. stands whose constituent species are socially compatible and which suit the site conditions, whilst mimicking nature in terms of planting density (with narrow planting intervals). Other more suitable, less expensive alternatives should be examined, such as:

- the use of natural regeneration,

- the use of shade as a principle of regulation and nurture,

- the opportunity principle ("use that which nature provides free") as opposed to deterministic decisions (imposing a stand composition objective),

- allowing nature to take its course, i.e. imitating the natural processes of plant succession instead of composition types.

Opportunistic silviculture makes use of natural plant dynamics. In the long term, natural development produces somewhat regular stands of relatively poor species composition $[34,38]$. This is the case in temperate regions of Europe (though not for American conditions) and is due to the natural process of outmixing, or the virtual elimination of admixed tree species by suppressing them in the understorey. According to Miegroet [21], this natural process could be deemed as a split between "the forces of stabilisation and destabilisation". This is incompatible with the above-mentioned need for diversification. It is therefore necessary to find a compromise between silvicultural interventions which allow structuring and diversifying - and their costs. Multipurpose, opportunistic silviculture relies on a minimum number of necessary steering measures, which are applied to the natural process to ensure that the main objectives are achieved. For instance, ensuring that high timber value is produced along with species diversity and structure. The principal of biological rationalisation [36] takes inspiration from the maxim "let nature take its course in everything it provides you with free", which is in turn based on philosopher Francis Bacon's ancient adage (1620) "nature to be commanded must be obeyed" [5]. Though Bacon's Novum Organum addressed human nature rather than plants, his maxim is generally applicable; besides, it has been adopted for the forest by French foresters, notably Parade's well known aphorism "mimic nature, hasten its work".

Two areas of silvicultural research should be explored to develop techniques suitable for encouraging plant species diversity. The first includes the interaction between forbs and seedlings during early stand establishment. The second area focuses on steering stand development in the desired direction. This deals with the natural process of socialisation as a consequence of interspecific competition [24]. This paper outlines some solutions to both questions and presents some initial results.

\section{STRATEGIES OF NATURAL VEGETATION SUCCESSION}

Light regulation is the main factor, which allows phases of stand establishment to be controlled. It is responsible for the regeneration process of both vegetation and seedlings. In the long term, forest seedlings win the battle of plant succession because they are capable of acrotonic i.e. upright stem growth. However, during the seeding phase, tree seedlings, especially conifers on good site conditions, generally need more time to start their height development and so can be uncompetitive compared to weeds. As Mlinsek [14] states, forest seedlings are to herbaceous vegetation (herbs) what marathon runners are to sprinters. To be successful, natural regeneration methods need to provide the light conditions for optimal development of forest seedlings, while at the same time, curtailing over-exuberant development of accompanying vegetation. This is particularly the case for tolerant and semi-tolerant tree species.

Shade control aside, another method of reducing establishment costs is to let plant succession take its course, that is, to wait until natural seedlings or planted trees free themselves from competing vegetation. Many studies show that both planted and natural seedings can keep up over time, and overtake the weeds $[6,10,12]$. This applies to practically every herbaceous forb (phanerogams reproducing by annual or biennial seeds). This is why modern central European silviculture guides renounce vegetation cleaning treatments under these circumstances [7, 26, 27]. This method works only if plant cover is not excessive and not too thick. This depends on light and on the reproductive system of the plants species involved. Species that reproduce vegetatively, especially grasses or brambles, can spread out rapidly and colonise the floor very invasively. This generally does not cause problems if the weeds have not been pre-established. In this case only shading allows efficient control of the weed cover.

The principle of forb dispersal and settling represents the basic concept for developing an efficient silvicultural system based on opportunistic control of competition. Weeds either produce a great number of seeds, which allow them to disperse rapidly (annuals) or to occupy persistently (perennials), thanks to above-ground organs (till) or underground organs (rhizomes). The Raunkiaer classification, which is based principally on reproductive strategy (Fig. 1), allows for differentiation of weed categories. Dispersal speed otherwise depends on reproductive strategy: generative vs. vegetative (by layers, stolons, root sprouts).

This applies particularly when regeneration takes place over a large area, for example, after clearcuts. Irrgang's studies [14] of vegetation clearcuts in eastern Germany indicate that during the first two years, annual and biennial herbs are the dominant 


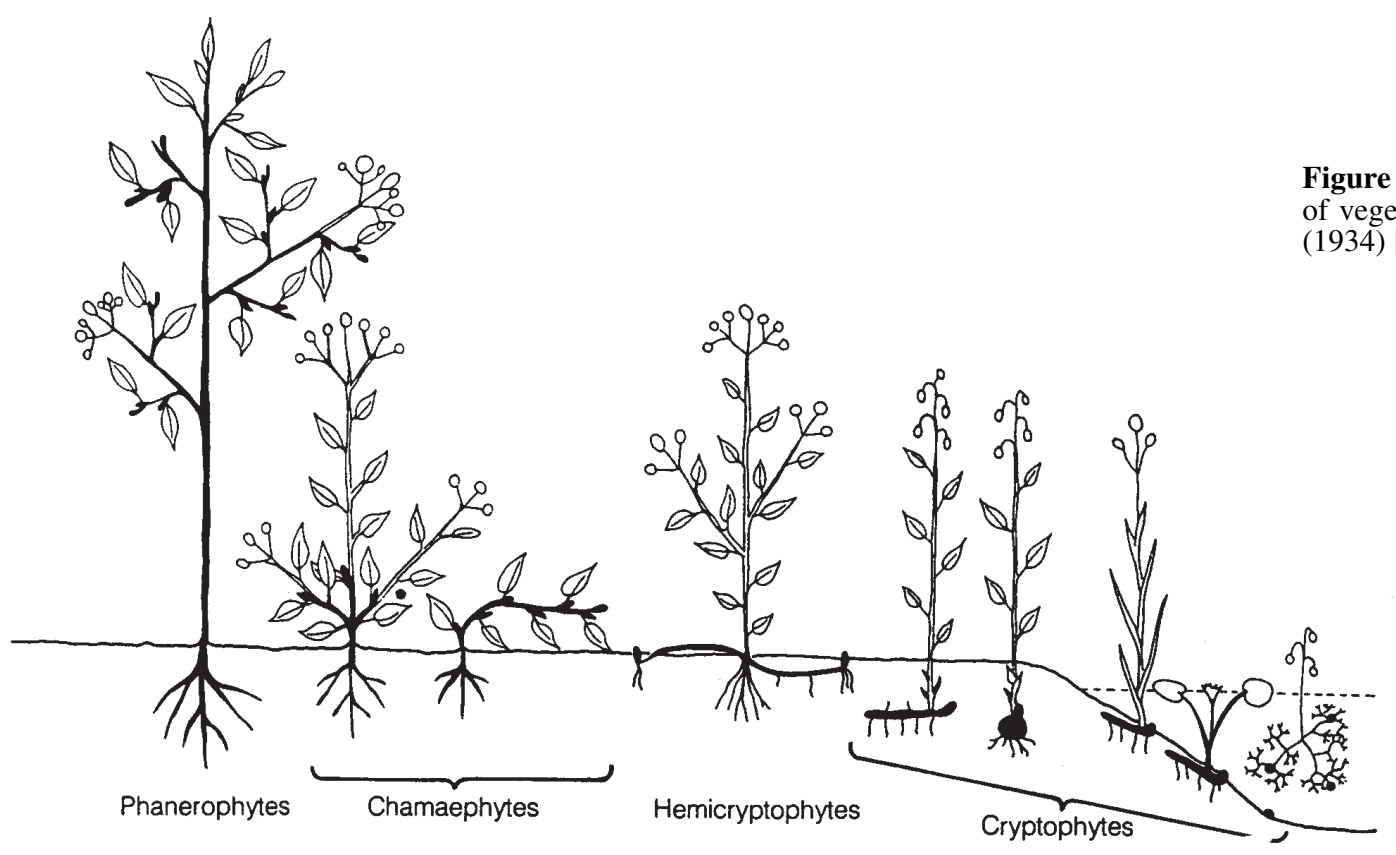

biomass components, because they disperse quickly through seed (partly from buried seed banks). In autumn, when they wither, they let free niches for establishment of other plants. This means that other vegetation elements, especially tree seedlings, can use these seasonal gaps in cover to successfully take hold. Grasses are more resistant, because they survive much longer and so occupy the soil perennially. They may invade the whole surface, especially after regular shelter cutting. They dominate vegetation dynamics for three to four years after clearcut; thereafter, woody plants take over.

\section{THE IMPORTANCE OF LIGHT REGULATION AND METHODS USED TO CONTROL LIGHT AVAILABILITY}

When proportioning shade and light during a natural regeneration process, one of the best compromises is to shift regeneration by creating successive gap openings in the old stand, which are lagged in time and space [35]. Using this method, forest seedlings stand a better chance of survival, provided they are not intolerant to shade. Silvicultural techniques, which use spatially and temporally lagged regeneration principles, such as the irregular group regeneration technique (the so-called "femel system") optimise light penetration to the floor, and so improve the natural regeneration process [9, 17, 35]. This silvicultural system has been applied on a large scale in Switzerland for many years. It represents a good solution to the issue of opportunistic renewal. To ensure that forest seedlings are not overgrown by competing vegetation, it is important to prevent weed cover developing too thick and too compactly. Once seedlings have developed an adequate root system (after 2 to 7 years) and possess a strong stem with sufficiently developed buds [11], the best growth occurs in full light [3, 4, 23]. For this reason, the original relatively small gaps of the irregular group regeneration system are expanded to increase light conditions.
The presence of shade makes it easier to control weed growth, even in the case of refractory invasive plants, such as brambles (Rubus fructicosus agg.) [33]. This vegetation is particularly difficult to control because of its long-lasting seasonal growth and ability to reproduce vegetatively, using layers of long shoots. This allows it to spread out extremely rapidly, especially under full light conditions. Brambles prefer artificial stands, especially conifer monocultures. Schreiner [33] showed that spruce can grow through under a bramble cover of less than 0.6 , and fir can grow under a cover of less than 0.8 (Fig. 2).

In addition to the technique of regeneration in gaps, shade control can be achieved by regularly opening the cover (shelterwood) or by creating anticipated shelters. However, the shelterwood system is less efficient than irregular gaps for steering natural regeneration, (except in the early stages of seedling establishment), because it brings more shade than light [35]. Here, the influence of tree species is decisive. Horn [12] showed that crown transparency differs according to tree species: this means the capacity to intercept light and to assist the regenerative process varies according to canopy species. Within broad-leaved tree species, the so-called multi-layers (where leaves and twigs are more or less parallel to sunbeams) are particularly suited to this purpose.

After a clear cut or a climatic event (such as a storm), the development of weeds (such as brambles) can be controlled by promoting the development of a new shading shelter. This can consist of fast growing translucent tree species like birch (Betula pendula Roth.), aspen (Populus tremula L.), rowan (Sorbus aucuparia L.) or even ash (Fraxinus excelsior L.), which exert a so-called "cooperative effect". This is possible even in the case of intolerant target species, such as oak. A number of studies show that even intolerant species like oak can grow without inconvenience in a mixture with birch, and actually display better form quality for up to 10 years after planting $[2,14,16,24$, 41] than on open-grown areas. 


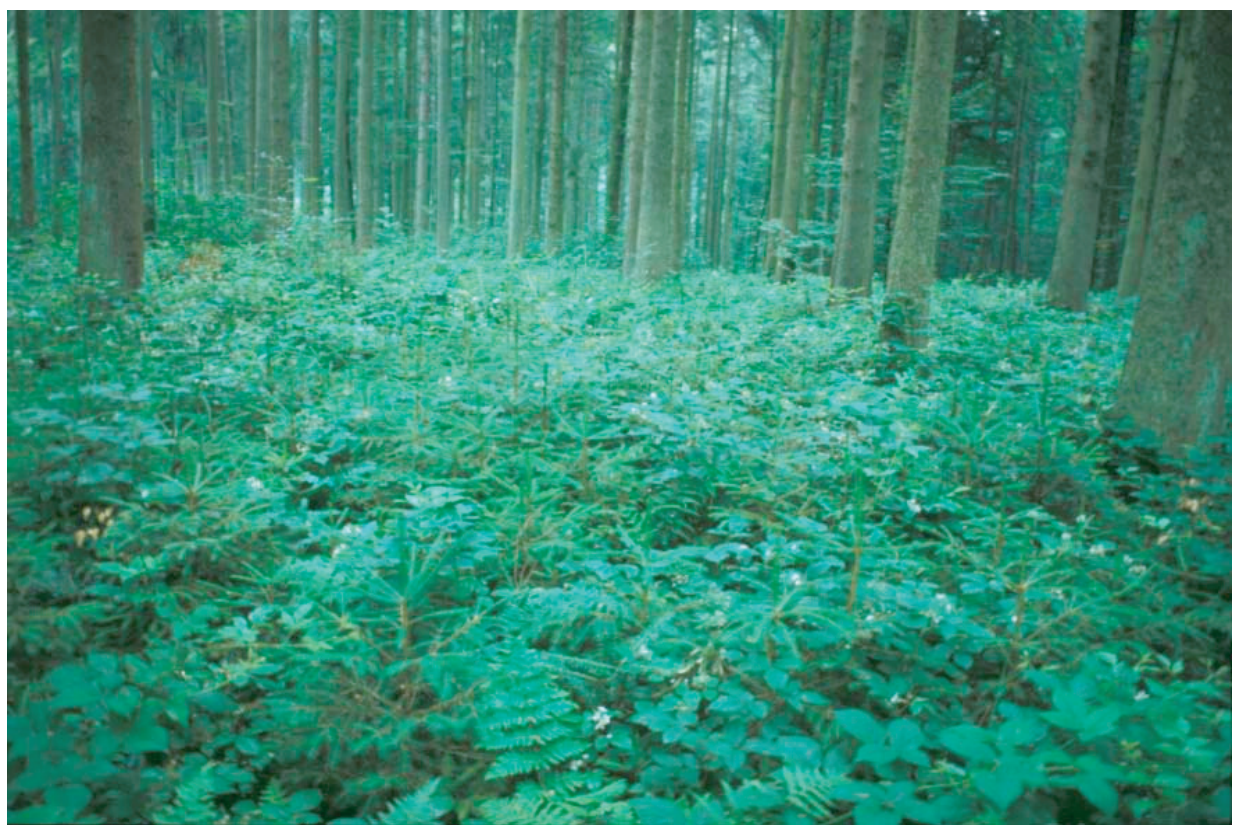

Figure 2. A shelter of 0.7 curtails excessive expansion of brambles, and thus allows spruce seedlings to grow through the vegetation cover. Forest of Schaffisheim, Swiss Midland.

\section{DIRECT SOWING OF STEERING VEGETATION TO IMPROVE FOREST SEEDLINGS}

The principle of antibiosis [25] can be used as a tool for steering forest seedlings and hindering competing vegetation. Antibiosis is a generic term that defines the influence (positive or negative) of plants on one another. Allelopathy represents only one type of antibiosis (this term is reserved solely for the chemical effect of one plant on another). Other forms, such as soil occupancy, are interesting from a practical point of view. Therefore, sowing favourable herbs just before, or during stand regeneration has been shown to assist tree seedlings from invading weeds $[26,31]$. These techniques also work with plantation.

One example of where controlled sowing offers genuine regeneration assistance is illustrated in Figure 3. Here, a subspontaneous annual plant, Royle's balsam (Impatiens glandulifera Royle), has been sown: it is sufficiently invasive to grow successfully, but has a favourable effect on the soil's biological activity (or other factors, for example, space occupancy), which deters and prevents excessive bramble development. Due to rapid spring growth, balsam prevents the long bramble shoots from coming into contact with soil, and thus stops them rooting. Like most annuals, balsam senesc quickly in summer after fruiting, and so does not hinder the growth of oak seedlings to a great extent. Furthermore, its favourable $\mathrm{C} / \mathrm{N}$ ratio helps promote biological activity and enriches the soil's humic horizon, which puts brambles at a disadvantage, according to Schreiner [33]. The results are very successful.

Similar experiments have been carried out successfully in Germany, where different forb mixtures like trifoil (Trifolium sp.), lupin (Lupinus sp.), buckwheat (Fagopyrum vulgare Hill), rye (Secale cereale L.), wheat (Triticium vulgare Vill.), mus$\operatorname{tard}$ (Sinapsis sp.), and others [10, 26, 31] have been sown. Such experiments demonstrate that the ingenious use of interspecific competition effects can provide interesting solutions to these problems.

\section{THE PRINCIPLES OF NATURAL MIXING AND OUTMIXING}

The presence of light not only controls the relationship between seedling development and weeds, but also exerts an influence on tree species diversity, thus controlling the tree species mixture relationship. Shade tolerant species prefer to settle under the shelter of an old stand, shade intolerant ones prefer to be more exposed. This means that silviculturists can use shading to influence species composition. To fully understand the differentiation process within tree species mixtures in a stand, we must consider the effect of other factors on the mixture's fate, for example, the intrinsic competitive reaction of different tree species due to differences in height growth and other competitive effects. Some species are very dominant, even exclusive (climax species); others are less competitive (commensals). Where cleaning operations are not carried out to counteract outmixing tendencies, less competitive single mixed species tend to disappear with time, allowing the dominant species to build up a more monospecific stand. Natural processes therefore result in stand outmixing.

To understand not only this phenomenon of complex cohabitation between tree species during stand regeneration, but also the phenomenon of natural outmixing, we set up an observation trial in an area of natural regeneration under a canopy gap. This was created specifically for regeneration during the winter of 1987/1988 at Affoltern, Switzerland, using the irregular group system technique, in an old broad-leaved mixed stand originating from coppice with standards. Natural regeneration development was recorded along two transects (Fig. 4) through the above-mentioned regeneration gap. Regeneration was measured 


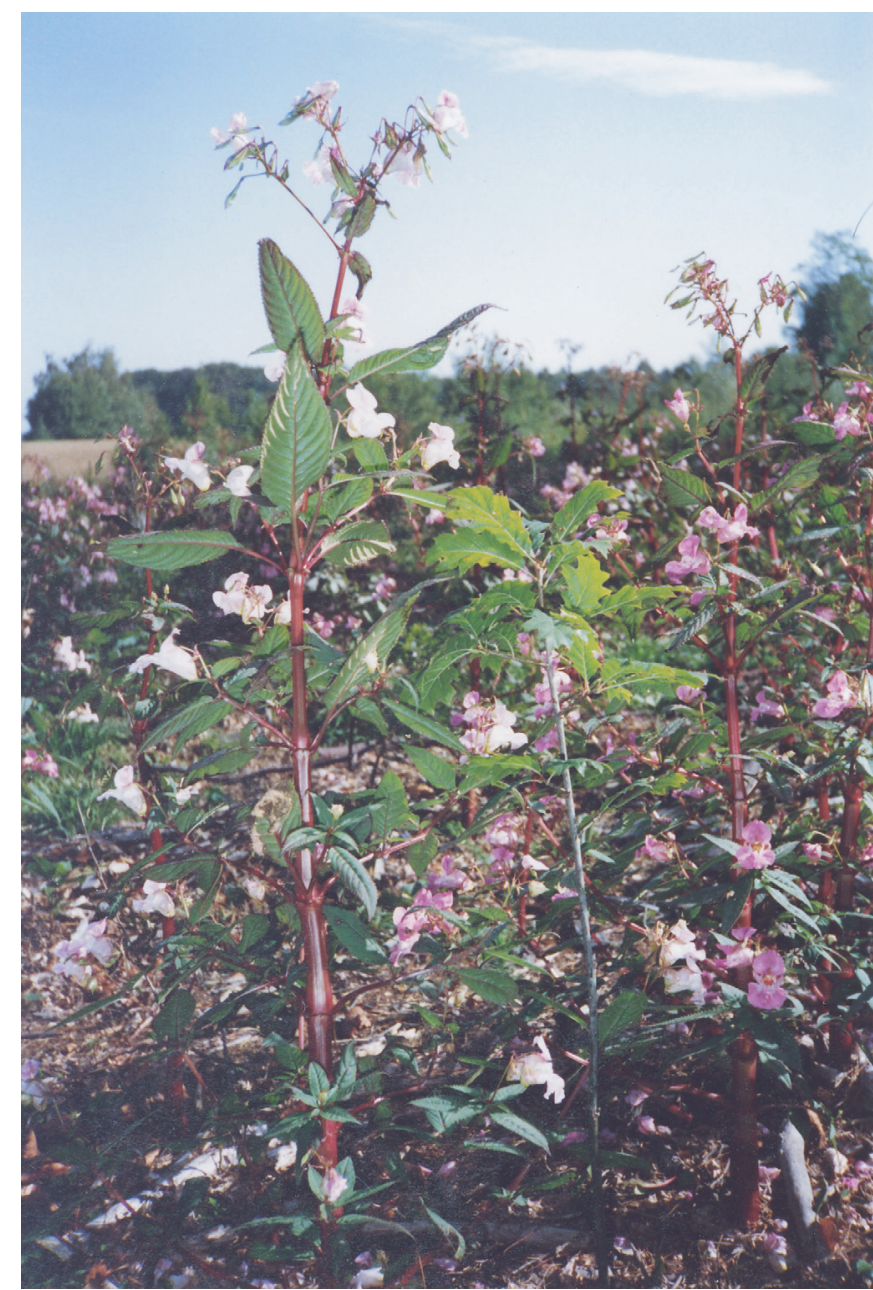

Figure 3. Development of an oak plantation where Royle's balsam has been sown to prevent bramble invasion. Method developed in Switzerland by W. Schenk (Photo: W. Kreis).

from the seedling stage to sapling stage, from 1989 to 2001 (13 years). To examine natural regeneration dynamics, cleaning practices were not applied in the gap.

\subsection{Material and Methods}

Location: Corporative Forest of Affoltern; $47^{\circ} 17^{\prime} \mathrm{N}, 8^{\circ} 28^{\prime}$ E. Elevation about $610 \mathrm{~m}$ asl. Topography: small hill, slight incline (2-5\%) in all directions. Site conditions were typical of fairly good forest sites in the Swiss Midlands, with adequate precipitation $(1190 \mathrm{~mm} / \mathrm{Y})$, a mean temperature of about $8^{\circ} \mathrm{C}$, and enough trophic nutritive status (geological substrate was a calcareous morainic layer); mull brown earth soil type. Climax vegetation was a eutrophic beech forest with good base saturation (Galio odorati Fagetum pulmonarietosum, synonym: Asperulo Fagetum) to moist beech forest (Aro-Fagetum). Two years before creating the gap, a light preparative seed cutting was undertaken so that conditions were optimal for seedling installation. Before this first seed cutting, the stand was very dense. We can therefore assume that the seedlings date from the same year. Old stand characteristics: a mixed stand from former coppice with standards. Main tree species were beech, ash, sycamore, oak and hornbeam, with some spruce and firs. Standing volume about $475 \mathrm{~m} 3 / \mathrm{ha}$.

The presence and height of natural regeneration was recorded on 65 single plots $(2 \times 2$ metres $)$ along the transects. All tree seedling numbers were assessed until 1992; from then on, young tree numbers were recorded according to height class (over-storey and under-storey). Damage was recorded (measuring browsing of leader shoots), especially from roe-deer browsing (Capreolus capreolus L.). Inventories were repeated every year from 1989 (year 3) until year 6, and subsequently every two years until year 12; the last inventory was carried out in 2001 (year 15). Height was measured using a telescopic rod. By the last inventory, tree height was measured sample-wise (with a VERTEX hypsometer, from Forestor Instruments, Täby, Sweden); height was assessed by measuring angles and distances with ultrasonic pulses and attributed according to measures of DBH of the over-storey trees. The top height was defined as the maximal height of tree species per plot. At the start of the trial (1989), the shade from the boarding trees of the old stand in the surrounding gap was assessed for every other plot, using hemispherical photographs and subsequent determination of relative diffuse radiation using Anderson's [1] radiative network. Because the gap was (unwillingly) slightly extended during 1996/97 to analyse light effects, the plots were classed into three light condition classes (light, intermediate and shady), based on a crown projection map.

Total tree numbers were recorded up to year 7 , thereafter, only trees belonging to the dominant storey were recorded.

\subsection{Results and discussion}

A very dense and fairly diversified seedling mixture was established, with a seedling density of about 670 thousand/ha in year 3 (1989). The crop was made up of 20 different tree species. 18 of them were broad-leaved species, two were conifers (spruce and fir); the latter were disadvantaged from the outset, which is usual in such site conditions. Of the 18 broad-leaved species, four spread out sufficiently and accounted for $98 \%$ of the crop: ash (Fraxinus excelsior L.), beech (Fagus silvatica L.), sycamore (Acer pseudoplatanus L.) and hornbeam (Carpinus betulus L.). Only disseminated elms (Ulmus glabra Huds.) and some birches (Betula pendula Roth.) were able to persist sporadically in the main crop. Cherry (Prunus avium L.) and oaks (Quercus pedunculata Ehrh. and Q. sessiliflora Salisb.) were insufficiently competitive to persist in the over-storey. Other tree species were of little importance.

Light conditions had a significant effect on height growth and species mixture. In this medium-sized gap ( 0.15 ha at the beginning, about 0.25 ha after 1996/1997), intolerant tree species (ash and sycamore) developed in the gap centre, and tolerant ones (beech, hornbeam) in the directly or indirectly shadowed parts (against and under the gap edge). Figure 5 shows the top height distribution of the different plots after eight years compared to relative light at the start of the trial. Ash, an intolerant tree species, reached heights of 3 to $4 \mathrm{~m}$ in conditions of $50 \%$ light availability and only 1 to $1.5 \mathrm{~m}$ in shady parts (less than $25 \%$ light). The same applied to sycamore, although ash outgrew it in practically every case. Beech grew tallest in medium light conditions (between $30 \%$ and $40 \%$ light). Above this level 


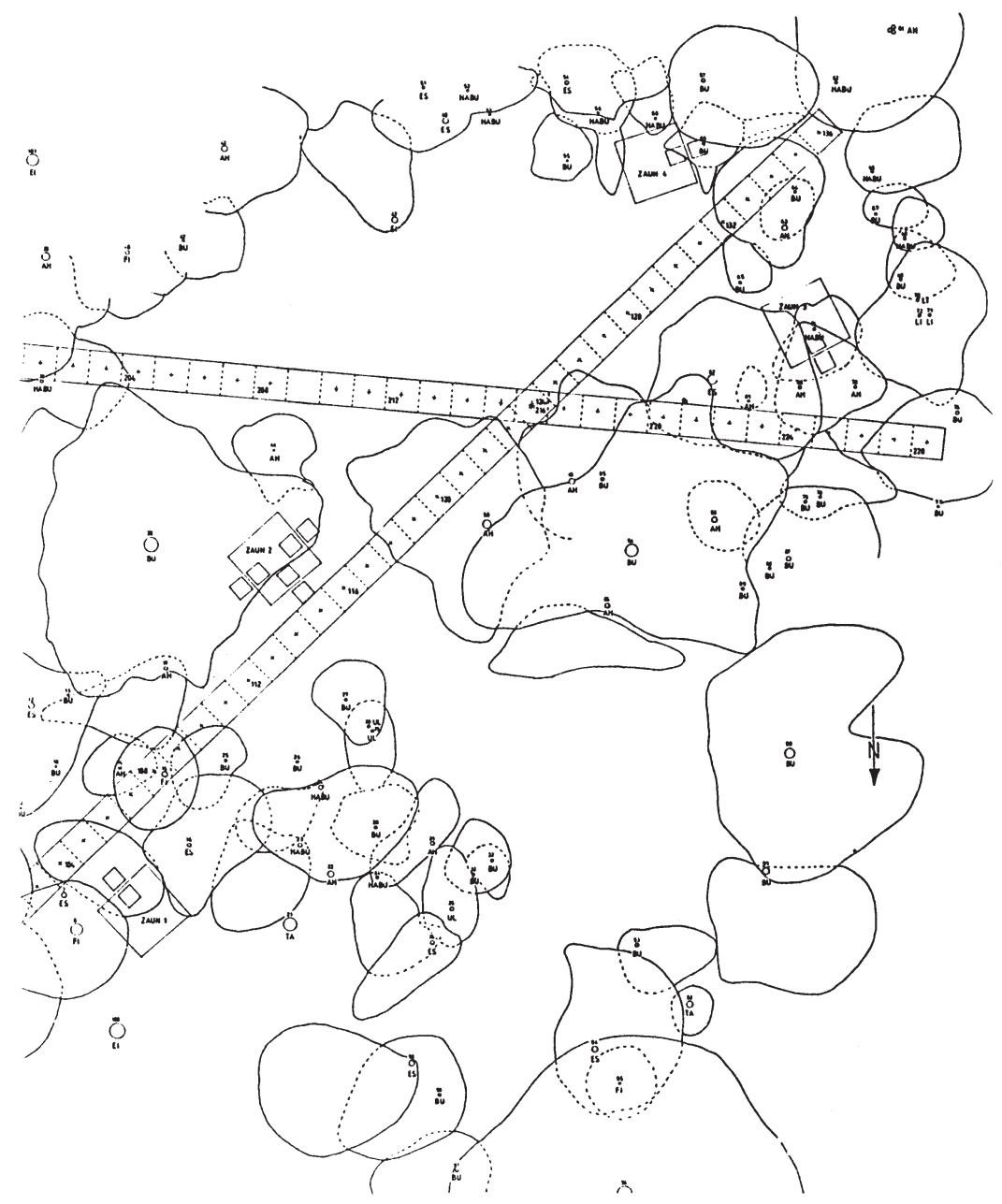

Figure 4. Design of the trial at Affoltern, with the location of the two transects through the regeneration gap.

it was suppressed, because ash and sycamore developed better. Below $30 \%$, beech trees reached $2.5 \mathrm{~m}$ but dominated other intolerant species. Hornbeam was midway between the two.

To assess the process of social differentiation over time, trees were separated into three data subsets according to the actual light climate i.e. taking into account subsequent gap enlargement (Fig. 6). Up to year 7, tree numbers were given as the total number of seedlings, and thereafter only the number of trees in the dominant storey. Results are consistent with those observed for height development. In good light conditions (>35\%), ash began with $48 \%$ cover occupancy, and reached $95 \%$ at age 15 (with a height of about 8 to $10 \mathrm{~m}$ ). In shady conditions $(<15 \%)$, beech began at $12 \%$ and reached $82 \%$ occupancy at age 15 . The outmixing effect is evident. Ash and beech can only compete in intermediate light, where beech tends to dominate, reducing the number of sycamores. The latter have virtually no opportunity to dominate.

This leads to the conclusion that two species tend to dominate, and suppress (probably eliminate) the others, in the long
Topheight in 1994 in relation to relative diffuse radiation age 8

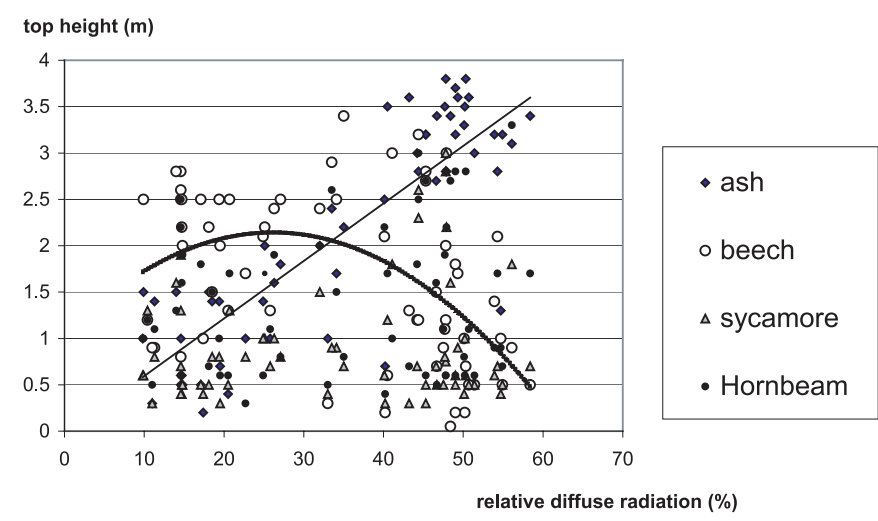

Figure 5. Top height of the four tree species after eight years relative to light conditions. 

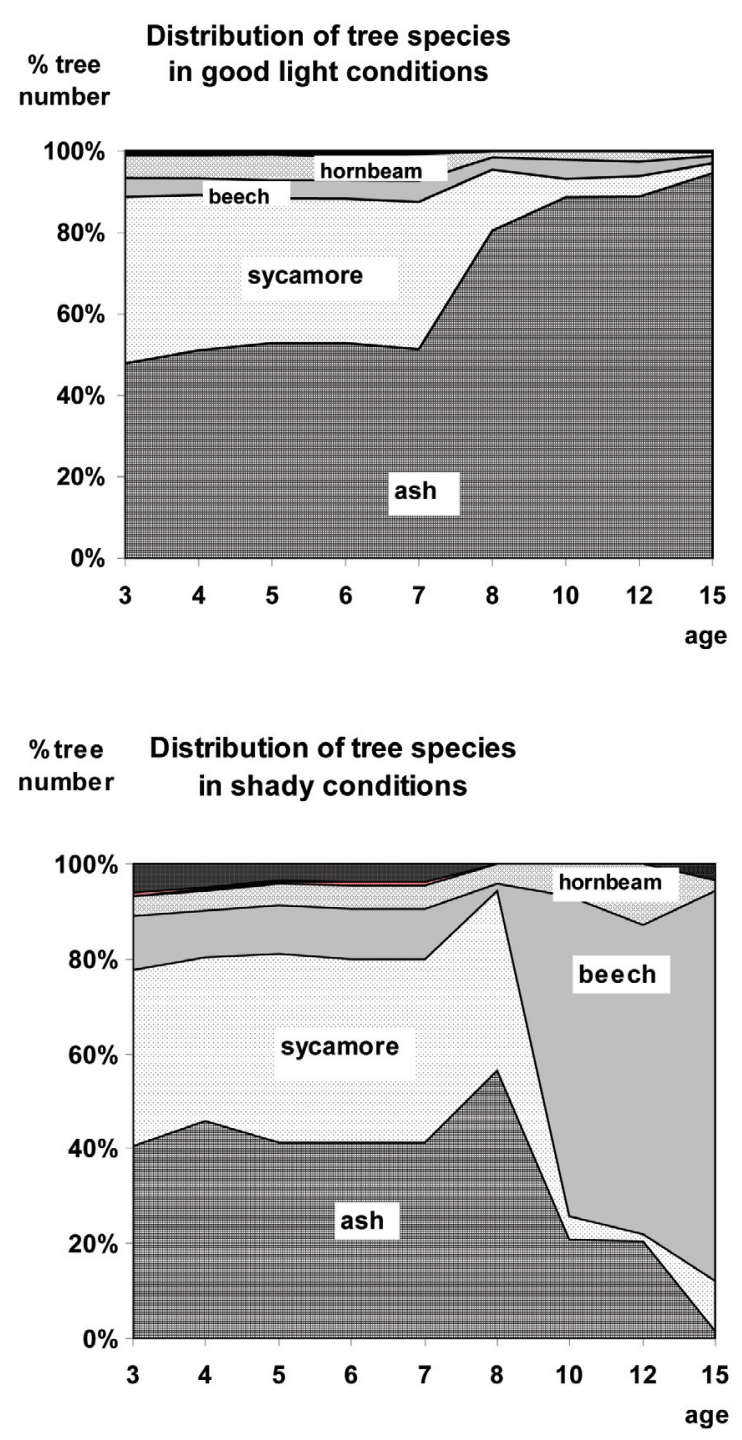

$\%$ tree Distribution of tree species number in intermediate conditions

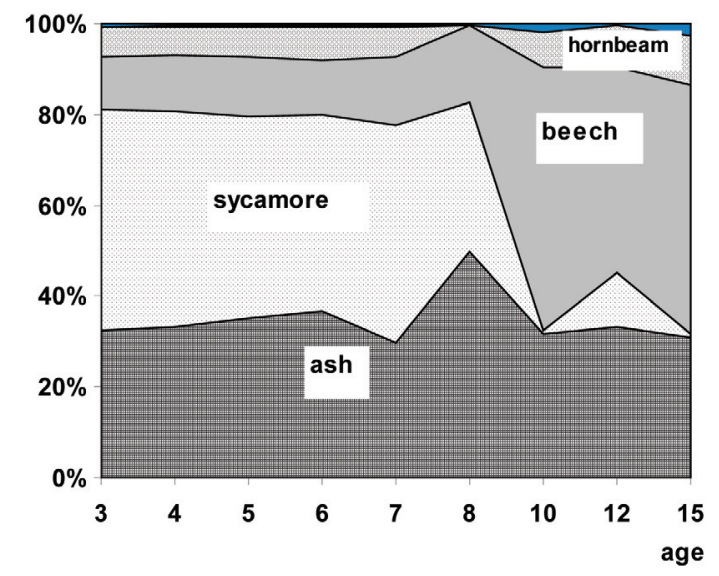

Figure 6. Evolution of the distribution of tree numbers in the overstorey between years 3 and 15 . run: ash, in good light conditions and beech in shady conditions. The study confirmed that cherry and oaks are not given the opportunity to dominate. This was unsurprising, as both tree species are known to be uncompetitive. More surprising was the clear decline of sycamore, as its silvicultural behaviour is generally considered to be similar to ash. Moreover, in some countries such as Belgium and Great Britain, comparable observations have provided contradictory results, by concluding that sycamore tends to surpass and eventually to suppress ash $[20,39,40]$. In addition, the possible problem of species alternation arises for ash and sycamore: pure stands offer more favourable conditions for the regeneration of the other species [39]. This seems to apply more to ash than sycamore. Neither my studies, nor research carried out by others can explain the reason for these differences in behaviour between ash and sycamore. It seems probable that ash only dominates sycamore under optimal soil and nutrition conditions: enough clay content and with high base saturation. Weber-Blaschke et al. [42] used pot experiments to demonstrate that the ecologic stability of ash decreased substantially on acidic soils with high Al concentrations, while this was not the case for sycamore.

Despite this, it seems clear that intrinsic competitive effects tend towards outmixing more often than previously thought. In some circumstances they are more important than the wellknown effects of light/shade. The main conclusion is that when nature is allowed to take its course, some homogenisation occurs. In the long run, this means that considerable early supportive silvicultural measures are required to maintain intimate mixed stands and to control their density. These measures become more incisive, the more significant the differences in sociability between the species. Silvicultural interventions are required to ensure species diversity. Opportunistic silviculture needs to fully understand these driving forces to reach a compromise, which can compensate for the effects of homogenisation.

Acknowledgements: I would like to express my thanks to the two anonymous referees whose helpful remarks, comments and suggestions have greatly helped to improve this paper.

\section{REFERENCES}

[1] Anderson M.C., Studies of woodland light climate, J. Ecol. 52 (1964) 27-41.

[2] Ammer C., Dingel C., Untersuchungen über den Einfluss starker Weichlaubholzkonkurrenz auf das Wachstum und die Qualität junger Stieleichen, Forstwiss. Centralbl. 116 (1997) 346-357.

[3] Aussenac G., Influences du couvert forestier sur la croissance de quelques résineux dans le jeune âge, Can. J. For. Res. 7 (1977) 8-18.

[4] Aussenac G., Interactions between forest stands and microclimate: Ecophysiological aspects and consequences for silviculture, Ann. For. Sci. 57 (2000) 287-301.

[5] Bacon F., Aphorism concerning the interpretation of nature, in: Speddling, Ellis \& Herath (Eds.), Novum Organum, Vol. 4: Instauration magna, Longman, London, 1620.

[6] Burschel P., Binder F., Bodenvegetation - Verjüngung - Waldschäden, Allg. ForstZ. 48 (1993) 216-223. 
[7] Burschel P., Schmaltz J., Untersuchungen über die Bedeutung von Unkraut- und Altholzkonkurrenz für junge Buchen, Forstwiss. Centralbl. 84 (1965) 230-243.

[8] Collet C., Lanter O., Pardos M., Effects of canopy opening on height and diameter growth in naturally regenerated beech seedlings, Ann. For. Sci. 58 (2001) 127-134.

[9] Diaci J., Experimentelle Felduntersuchungen zur Naturverjüngung künstlicher Fichtenwälder auf Tannen-Buchenwaldstandorten (Homogyno sylvestis-Fagetum) in den Savinja-Alpen (Slowenien) mit besonderer Berücksichtigung der Ansamungsphase und unter dem Einfluss der Faktoren Licht, Vegetation, Humus und Kleinsäuger, Diss. ETH-Z, Zürich, 1995.

[10] Denecke F., Jungwuchspflege und Standortssanierung durch Nutzpflanzendecken, Allg. ForstZ. 43 (1988) 221-222.

[11] Fontaine F., Druelle J.-M., Clément C., Burrus M., Andran J.-C., Ontogeny of proventious epicormic buds in Quercus petraea. I. In the 5 years following initiation, Trees 13 (1998) 54-62.

[12] Gerry A.K., Wilson S.D., The influence of initial size on the competitive response of six plant species, Ecology 76 (1995) 272-279.

[13] Horn H.C., The adaptive geometry of trees, Princeton Univ. Press, Princeton, 1971.

[14] Irrgang S., Dynamik der Artstruktur sowie der Biomassenproduktion und -akkumulation in den ersten Jahren nach Kahlschlag, Arch. Naturschutz Landsch. Forschung 30 (1990) 231-252.

[15] Jenny H.P., Vor lauter Bäumen den Wald doch noch sehen; Ein Wegweiser durch die neue Waldgesetzgebung. Schriftenr. Umwelt Nr 210, BUWAL, Bern, 1993.

[16] Leder B., Weichlaubhölzer; Verjüngungsökologie, Jugendwachstum und Bedeutung in Jungbeständen der Hauptbaumarten Buche und Eiche, Schriftenr. Landesanst. Forstw. Nordr.-Westf., Sonderband, Zimmermann, Balve, 1992.

[17] Mayer H., Waldbau auf soziologisch-ökologischer Grundlage, Fischer, Stuttgart, 1992.

[18] Miegroet M.v., Concepts of forest stability and forest management, Silva Gandavensis 50 (1984) 39-64.

[19] Miegroet M.v., The choice of tree species as a strategical concept, Silva Gandavensis 50 (1984) 85-100.

[20] Miegroet M.v., Verhegghe J.F., Lust N., Trends of development in the early stages of mixed natural regeneration of ash and sycamore, Silva Gandavensis 48 (1981) 1-29.

[21] Miegroet M.v., The choice of tree species as a strategical concept, Silva Gandavensis 50 (1984) 85-100.

[22] Mlinsek D., Sproscena tehnika gojenja gozdov na osnovi nege, [The free silviculture technique based on tending], Poslovno zdruzenje gozdnogospodarskih rganizacij v Ljubljani, Ptujska tiskarna, 1968.

[23] Mosandl R., El Kateb H., Die Verjüngung gemischter Bergwälder - Praktische Konsequenzen aus 10 jähriger Untersuchungsarbeit, Forstwiss. Centralbl. 107 (1988) 2-13.

[24] Nüsslein S., Birken wirken wuchsfördernd, Allg. ForstZ. 54 (1999) 615.
[25] Odum E.P., Fundamentals of ecology, 3rd ed., Saunders, Philadelphia, 1971.

[26] Olberg R., Wie reagieren Fichten-Kulturen auf Unkrautbekämpfung? Allg. Forst u. J.-Ztg. 145 (1974) 212-219.

[27] Olberg-Kallfass R., Zur Reaktion von Fichten auf Unkrautbekämpfung in der Kultur, Allg. Forst u. J.-Ztg. 150 (1979) 191-195.

[28] Ozenda P., Végétation du continent européen, Delachaux et Niestlé, Lausanne, 1994.

[29] Raunkiaer C., The life forms of plants and statistical plant geography, Clarendon Press, Oxford, 1934.

[30] Reinecke H., Aufforstung von Windwurfflächen unter Nutzpflanzen möglich, Allg. ForstZ. 45 (1990) 950-955.

[31] Reinecke H., Begleitwuchsregulierung, Bestandesbegründung mit Schutz-pflanzendecken, Eigenverlag, Göttingen, 2001.

[32] Schärer W., Zimmermann W., Politische und rechtliche Betrachtungen zum Thema Waldsterben in der Schweiz; Eine Standortsbestimmung, Beih. Z. Schw. Forstverein Nr. 72, 1984.

[33] Schreiner M., Vorkommen und Ausbreitung von Brombeeren sowie ihre Bedeutung für die Naturverjüngung von Tannen-Fichten-Wäldern; dargestellt am Beispiel der Region "Oberer Neckar", Agrarforsch. In Baden-Württemberg, Bd. 31, 2001.

[34] Schütz J.-P., Sylviculture 2. La gestion des forêts irrégulières et mélangées, Presses Polytechniques et Universitaires Romandes, Lausanne, 1997.

[35] Schütz J.-P., Licht bis auf dem Waldboden; Waldbauliche Möglichkeiten zur Optimierung des Lichteinfalls im Walde, Schweiz. Z. Forstwes. 149 (1998) 843-864

[36] Schütz, J.-P., Neue Waldbehandlungskonzepte in Zeiten der Mittelknappheit; Prinzipien einer biologisch rationellen und kostenbewussten Waldpflege, Schweiz. Z. Forstwes. 150 (1999) 451-459.

[37] Schütz J.-P., Der Plenterwald und weitere Formen strukturierter und gemischter Wälder, Parey, Berlin, 2001.

[38] Spellmann H., Überführung als betriebliche Aufgabe, Forst u. Holz 54 (1999) 110-116.

[39] Tabari M., Lust N., Nachtergale L., Regeneration dynamics in an alluvial dense ash (Fraxinus excelsior $\mathrm{L}$.) stand, Silva Gandavensis 66 (2001) 57-67.

[40] Walters T.L., Savill P.S., Ash and sycamore regeneration and the phenomenon of their alternation, Forestry 65 (1991) 417-433.

[41] Wagner S., Röker B., Birkenanflug in Eichenkulturen; Untersuchungen zur Dynamik der Konkurrenz über 7 Vegetationsperioden, in: Tagungsber. 13. Arbeitstagung Sekt. Waldbau im Deutsch. Verb. Forstl. Forschungsanst., 9-11 Sept. 1998 in Eberswalde, 1999, pp. $105-122$.

[42] Weber-Blaschke G., Claus M., Rehfuess K.E., Growth and nutrition of ash (Fraxinus excelsior L.) and sycamore (Acer pseudoplatanus L.) on soils of different base saturation in pot experiments, For. Ecol. Manage. 167 (2002) 43-56.

[43] Zimmermann W., Erhaltung und Verbesserung des Waldzustandes: Katalog möglicher staatlicher Massnahmen, Forstwiss. Beiträge 3, Fachber. Förstökonomie und Forstpolitik ETH, Zürich, 1986. 